\title{
The Economic Efficiency of Traditional and Islamic Banking (a Comparative Analysis of the Turkish, Azerbaijani, and Iranian Banking Sectors)
}

\author{
Mayis G. Gulaliyev (iD https://orcid.org/0000-0001-7614-7322 \\ Ph.D., Associate professor of the Azerbaijan State University of Economics (UNEC), \\ head of the Department at the Institute of Economics of Azerbaijan National \\ Academy of Sciences, Baku, Azerbaijan, e-mail: mayis_gulaliyev@yahoo.com
}

Elmar N. Rahimov (iD https://orcid.org/0000-0002-2291-8651

Ph.D. Candidate at the Institute of Economics of Azerbaijan National Academy of Sciences, Baku, Azerbaijan, e-mail: elmar.rahimov@yahoo.com

Flora Sh. Kashiyeva (iD) https://orcid.org/0000-0002-4858-897x

Ph.D., Associate professor at Azerbaijan State University of Economics (UNEC), Baku, Azerbaijan, e-mail: flora_kashiyeva@unec.edu.az
Alida T. Huseynova (iD) https://orcid.org/0000-0002-8861-2612 Ph.D., Senior lecturer at Azerbaijan State University of Economics (UNEC), Baku, Azerbaijan, e-mail: alida_gusenova@unec.edu.az

Shahla M. Alijanova (iD https://orcid.org/0000-0002-3115-2635

lecturer at Azerbaijan State University of Economics (UNEC), Baku, Azerbaijan, e-mail: shahla.musaqizi@gmail.com

\section{Yegana A. Hakimova (iD https://orcid.org/0000-0001-5686-4105}

Senior lecturer at Azerbaijan State University of Economics (UNEC), Baku, Azerbaijan, e-mail: hekimli.2014@mail.ru 


\section{Abstract}

The article attempts to develop a methodology for a comparative assessment of the economic efficiency of banks, including traditional and Islamic banking models. The assessment shows that the stability of financial institutions in Azerbaijan is lower compared to banks where Islamic banking is used. The assessment also shows that there is a strong dependence of the GDP growth rate on the sub-indices of the effectiveness of financial institutions in Azerbaijan, Turkey, and Iran. The methodology of linear regression and a composite index of the economic efficiency of banks are applied. The assessment shows that the influence of the stability of the financial system on economic growth in Azerbaijan, Iran, and Turkey is different. The economic growth rate and the ratio of bank loans to bank deposits in Azerbaijan and Turkey are positively related, but negatively in Iran.

Keywords: financial institutions, access to financial institutions, the depth of financial institutions, the effectiveness of financial institutions, the stability of financial institutions

JEL: G21

\section{Introduction}

In the cycle of economic relations, banks play the role of intermediary. However, this intermediary, operating in the money market, also affects the market for goods and services.

Banks accept the unspent part of economic entities' income as savings on certain conditions and transfer them to other entities that need funds on other conditions, such as a loan. Funds that are a deposit for one entity and remain unused can turn into a production factor for another entity, in the form of investment. In other cases, such loans increase aggregate demand, as they stimulate consumption and, indirectly, affect aggregate supply.

To fulfil their functions, commercial banks can receive loans from the Central Bank at a lower interest rate and provide them to economic agents at higher interest rates. In this case, loans provided by the bank either become production factors as investments or they increase the level of consumption and the aggregate demand of economic agents. The reverse process may also occur. That is, a reduction in the volume of bank loans can reduce the volume of financial resources - investments aimed at the production process, as well as reduce the volume of consumption. Thus, the aggregate demand curve will go to the left. Banks play an exceptional role in the existence of the economy, performing such functions as saving, lending, including current billing, among others.

Under the condition of ceteris paribus, different economic results of banking systems that differ in essence are also observed in traditional and Islamic banking models. 


\section{Literature review}

As early as 1912, Schumpeter noted that the development of financial institutions was important in stimulating economic growth (Schumpeter 1912). The Cobb-Douglas function, which is an important model of economic growth, also attracts the attention of TFP (technological factor of production) along with capital and labor. The development of education and health, as well as the development of financial institutions, is an integral part of this factor. In the economic literature, there are more frequent studies on the impact of financial institutions on economic growth.

Based on a study of the literature, we can unequivocally conclude that there is a causal relationship between financial development and economic growth, and financial development is recognized as necessary for economic development. However, no uniform relationships were identified. There are at least five hypotheses that have been found both at the national and regional levels, at different periods. The first hypothesis, in which financial development leads to economic growth, is the earliest and most popular.

Studies conducted by King and Levine (1993), De Gregorio and Guidotti (1995), and Khan and Senhadji (2000) also used transverse OLS or two-stage least squares regression. Despite differences in individual countries and variables, they found a significant positive relationship and confirmed that financial depth is a prerequisite for economic growth. Levine et al. (2000) studied the impact of legal reforms in finance and found that legal reforms are the determining factors in financial development and economic growth.

A study by Samargandi et al. (2015) argues that in the short run, there is a negative relationship between finance and economic growth. Even an inverted U-shaped connection is possible. This study used the ARDL model and concluded that financial development affects growth in different countries in different ways. In several studies, a relationship has been established between the development of the stock market, the financial and banking systems, and the growth of real GDP per capita (Estrada et al. 2010).

This suggests that institutional reforms in each country have different effects on economic growth, and that these reforms contribute to growth. This study used regression with a fixed and random effect. Similarly, Bayar (2014) used the same methods and discovered the positive impact of financial development on economic growth.

The second hypothesis is that economic growth stimulates financial development. Liang and Teng (2006) and Ang and McKibbin (2007) used the VAR infrastructure, co-integration, and causality tests to prove a close and unidirectional correlation, i.e., the reason for financial development was economic growth. Ang and McKibbin (2007) took into account the effects of financial repression. Financial repression, represented by the required reserves ratio, liquidity ratio, loans, and deposit rates, was negatively associated with financial depth and growth. But De Gregorio and Guidotti (1995) observed a negative correlation between financial liberalization and economic growth in Latin America. 
The third hypothesis is that economic growth and financial development stimulate each other. Many studies prove this. For example, Hassan et al. (2011) used OLS and WLS regression for the panel model and VAR for the time series. Borlea et al. (2016) did not mention the influence of financial institutions but used only financial market indicators such as market capitalization, stock trading volume, and turnover to represent financial development. These studies show a twofold orientation of cause and effect relationships between economic growth and financial development.

In the studies of Hye (2011), the ARDL model was used and, as an indicator of financial development, a PCA was built based on indicators of creditworthiness, money supply, and the stock market. Short-term and long-term negative links between financial development and growth were found. A study conducted by Al-Malkawi et al. (2012) found negative links between finance and growth. And this study showed an inverse but negative relationship between finance and growth in the United Arab Emirates.

In the study of Gulaliyev et al. (2019), a banking stability indicator (BSI) was calculated by using the Minimax normalization method. The composite index was used to analyse the financial stability of the banking sector in 29 countries and to build a risk map based on their national basic economic indicators. The proposed BSI index is intended both for comparative international assessment of the financial stability of the banking sector and for its evaluation in the country. It gives the ability in the most general form to assess the banking sector from the point of view of international competitiveness and to compare it with other countries.

Our paper comparatively investigates three different financial institutions' impacts on economic growth in different countries. Their distinguishing feature is related to the number of Islamic banks in their financial system. Iran's financial system fully includes Islamic banks, while Azerbaijan's financial system does not have any. Meanwhile, Turkey has a mixed bank system, i.e., it has an Islamic and traditional banking system. Thus, we try to compare these three financial systems' impacts on economic growth by comparing impacts of 1 ) access to banking sectors; 2) the depth of the financial institutions; 3 ) the effectiveness of the financial institutions, and 4) the stability of the financial institutions of these neighbour countries. As well as we used a composite index for an investigation that is different from composite indices, suggested by Svirydzenka, K. (2016) and Cámara, N. (2017) and etc.

Essential hypothesis: There are no differences between Islamic and traditional banking systems from an efficiency perspective.

\section{Methodology}

The access to financial institutions index covers 36 subindexes (GFDR 2018). Based on these indicators, a composite indicator, such as the Financial Institutions Access Index (FIAI), can be calculated to assess the level of development of a country's finan- 
cial system. This indicator can be obtained by indexing and summing the same weight of each of the above sub-indices, i.e.

$$
F I A I_{i, t}=\frac{1}{n} \sum_{j}^{n}\left(\frac{F I A_{i, j, t}-F I A_{t, \text { min }}}{F I A_{t, \text { max }}-F I A_{t, \text { min }}}\right)
$$

where, $F I A I_{i, t}$ - Index of Access to Financial Institutions of country $i$ in year $t$; $F I A_{i, t, j}$ - indexed value of subindex $i$ by subindex $j$ in year $t ; F I A_{t, \text { min }}$ - the minimum possible value of sub-index $j$ for the financial system of countries in year $t ; F I A_{t, \max }-$ the maximum possible value of sub-index $j$ for the financial system of countries in year $t$. For all subindexes, measured in percent, we can assume $F I A_{t, \min }=0$ and $F I A_{t, \max }=100$.

For the $6^{\text {th }}, 7^{\text {th }}$, and $8^{\text {th }}$ subindex, $F I A_{t, \text { min }}=0$, a $F I A_{t, \text { max }}$ can be taken, respectively, $100,000,1000$, and 100,000. We can compare the effectiveness of the banking systems of several countries, according to FIAI, using subindexes in which the principles of Islamic and traditional banking models may differ.

The Depth Index of Financial Institutions consists of 14 subindexes. Using these subindexes, the Financial Institutions Depth Index (FIDI) can be calculated. Such a composite index can be expressed by the formula:

$$
F I D I_{i, t}=\frac{1}{n} \sum_{j}^{n}\left(\frac{F I D_{i, j, t}-F I D_{t, \text { min }}}{F I D_{t, \text { max }}-F I D_{t, \text { min }}}\right)
$$

where, $F I D I_{i, t}$ - Index of Access to Financial Institutions of country $i$ in year $t$; $F I D_{i, t, j}$ - is the indexed value of subindex $i$ by subindex $j$ in year $t ; F I D_{t, \text { min }}$ - the minimum possible value of subindex $j$ for financial systems in year $t ; F I D_{t, \max }$ - the maximum possible value of subindex $j$ for financial systems in year $t$.

For all subindexes, measured as a percentage, we can assume $F I D_{t, \min }=0$ and $F I D_{t, \max }=100$. We can compare the efficiency of several countries' banking systems by FIDI using subindexes in which the principles of Islamic and traditional banking models may differ.

The effectiveness of the financial institutions index contains ten subindices. Based on these indicators, we can calculate the composite Financial Institutions Effectiveness Index (FIEI) as follows:

$$
F I E I_{i, t}=\frac{1}{n} \sum_{j}^{n}\left(\frac{F I E_{i, j, t}-F I E_{t, \text { min }}}{F I E_{t, \text { max }}-F I E_{t, \text { min }}}\right)
$$

where, $F I E I_{i, t}$ - Index of Access to Financial Institutions of country $i$ in year $t$; $F I E_{i, t, j}$ - is the indexed value of subindex $i$ by subindex $j$ in year $t$; $F I E_{t, \text { min }}$ - the minimum possible value of sub-index $j$ for the financial systems of countries in year $t$; $F I E_{t, \text { max }}$ - is the maximum possible value of subindex $j$ for the financial systems of countries in year $t$. For all subindexes, which are measured in percent, we can consider 


$$
F I E_{t, \min }=0 \text { and } F I E_{t, \max }=100 .
$$

The stability of financial institutions can be calculated using seven subindexes. For a comparative analysis of the stability of financial institutions based on these indicators, a composite index - the Financial Institutions Stability Index (FISI) - can be calculated as follows:

$$
F I S I_{i, t}=\frac{1}{n} \sum_{j}^{n}\left(\frac{F I S_{i, j, t}-F I S_{t, \text { min }}}{F I S_{t, \max }-F I S_{t, \min }}\right)
$$

where, $F I_{S I}$ - Stability Index of Financial Institutions of country $i$ in year $t$; $F I S_{i, t, j}$ - indexed value of subindex $i$ by subindex $j$; FIS $S_{t, \text { min }}$ - the minimum possible value of subindex $j$ for the financial systems of countries in year $t ; F I S_{t, \max }$ - the maximum possible value of sub-index $j$ for the financial systems of countries in year $t$. For all subindexes, which are measured in percent, we can consider $F I S_{t, \min }=0$ and $F I S_{t, \max }=100$. We can compare the effectiveness of several countries' banking systems by FISI using subindexes in which the principles of Islamic and traditional banking models may differ.

The Financial Development Composite Index (FDCI) can be calculated based on the four indices listed above as:

$$
F D C I_{i t}=F I A I_{i t}+F I D I_{i t}+F I E I_{i t}+F I S I_{i t}
$$

The OLS method is the most widely used method used to study the impact of development, including the access to depth, effectiveness, and stability of financial institutions on economic growth. Based on this method, the regression relationship between subindexes characterizing the rate of economic growth and the indicators of access, depth, effectiveness, and stability of financial institutions on economic growth can be expressed as:

$$
Y_{t}=\alpha_{0}+\sum_{i}^{n} X_{i t}+\varepsilon_{t}
$$

In this study, we will express as $Y_{t}$ both the rates of economic growth and the volume of GDP per capita at year $t$, and as $X_{i t}$ - indicator $i$ at year $t$.

\section{Data}

In the course of the study, we will consider some of the indicators used in the World Bank's Global Financial Development Report (GFDR 2018) as the main indicators characterizing the banking sector. This report contains indicators that characterize 
not only the activities of banks but also the activities of the financial system as a whole. However, since we are interested in a comparative analysis of the economic efficiency of traditional and Islamic banking models, we will use only indicators that relate to banks from the report. The World Bank, in its report "Global Financial Development," quantitatively measures the level of development of the financial sector, including the banking system, by country. The most recent report was conducted at the end of 2017 and covers 214 countries. The level of financial development is estimated based on 117 sub-indicators. The main indicators characterizing the development of the banking system are: 1) access to financial institutions; 2) the depth of financial institutions; 3) the effectiveness of financial institutions; 4) stability of financial institutions.

\section{Results}

\section{A comparison of the banking systems of Azerbaijan, Turkey, and Iran on the Financial Institutions Access Index (FIAI)}

Based on the methodology, we will consider $F I A_{t, \min }=0$, and $F I A_{t, \max }=1000$ for the $6^{\text {th }}$ and $7^{\text {th }}$ sub-indices. Thus, calculations show that for the financial systems of Azerbaijan, Iran, and Turkey for the period covering 2004-2016, the Financial Institutions Access Index (FIAI) had dramatically different dynamics. In Iran, which practices Islamic banking in general, the FIAI has an ever-growing dynamic. Only in 2016 did it fall slightly. Indicators for FIAI Azerbaijan are mainly lower than in Iran and Turkey. Only in 2009 and 2013 did Azerbaijan overtake Iran in this indicator. An interesting fact is that this indicator has a "wavy" character in both Azerbaijan and Turkey (Figure 1).

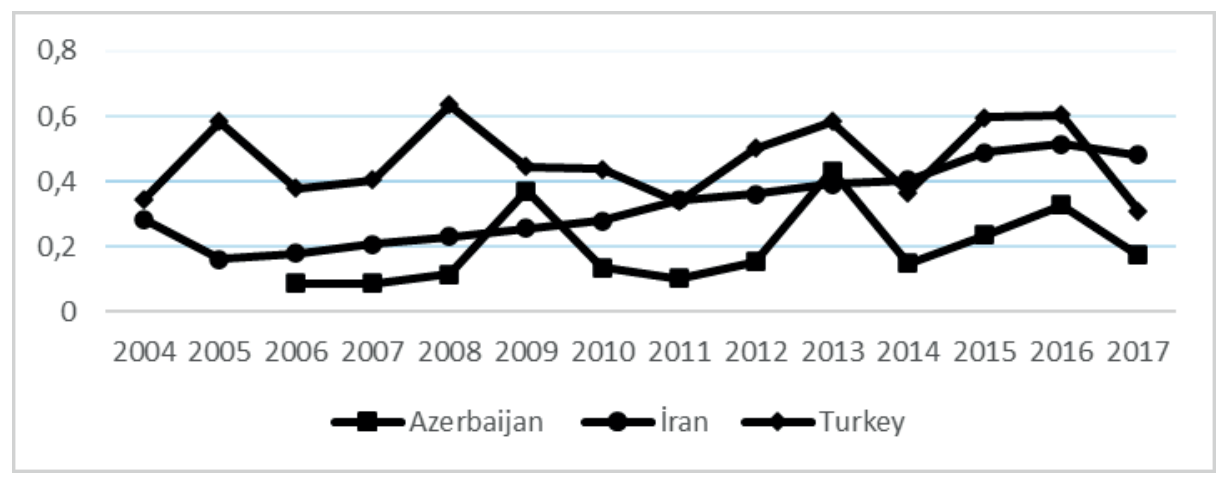

Figure 1. Dynamics of the Financial Institutions Access Index (FIAI) Source: authors' own elaboration based on GFDR (2018). 


\section{A comparison of the banking systems of Azerbaijan, Turkey, and Iran on the Financial Institutions Depth Index (FIDI)}

Azerbaijan's Depth of Financial Institutions Indicators for the period 1993-2016 show that only the dynamics in the "the ratio of liquid obligations to GDP" subindex is positive. Other indicators do not show steady growth. "The ratio of central bank assets to GDP" initially decreased (1993-1997), and then increased (2001-2010). During the period of rapid GDP growth in the country (2001-2010), this indicator sharply decreased and then increased again (2001-2015). After the devaluation of 2015, a slight decrease is observed. This upward and downward trend is not characteristic of Iran's financial institutions. The "ratio of central bank assets to GDP" in this country, where Islamic banking is used, generally decreased, from $14.5 \%$ (1993) to $2.4 \%$ (2016), although there were exceptions.

In Turkey, sharp "fluctuations" are not characteristic of this subindex. But despite this, against the background of changes accompanied by a slight fluctuation in the form of growth and decrease, the "ratio of central bank assets to GDP", with some exceptions, increased from 3.7\% (1993) to 9.4\% (2002), and in subsequent years it steadily decreased to $0.58 \%$ (2016). Thus, both in Turkey and Iran, there is a tendency for this indicator to decrease in the long term.

One of the most important differences between Islamic banking and traditional banking is the form of providing loans to the private sector. In many countries, banks believe that when lending to the private sector, participation in incomes instead of a specific interest rate creates additional risk for banks and, therefore, prevents the use of Islamic banking. However, Iran's high rating in terms of "the ratio of local credit for the private sector to GDP" indicates the possibility of achieving mutual trust and profitability in Islamic banking. Comparing the dynamics of this subindex for the period 1993-2016 shows that compared with Iran and Turkey, in Azerbaijan, the share of local loans directed to the private sector in GDP is much less. However, what is encouraging is that in Azerbaijan, the share of loans provided by banks to the private sector in the volume of GDP is steadily growing. The devaluation of the manat in 2015 significantly reduced this figure.

We can compare the depths of banking systems in Azerbaijan, Iran, and Turkey, according to the FIDI, using sub-indices that may differ in traditional and Islamic banking principles. Based on FIDI calculations for all three countries, we can note that the depth of financial institutions in Iran where Islamic banking is used is higher compared to Turkey, which uses Islamic banking, and Azerbaijan, which does not use it (Figure 2). In recent years, the tendency toward improving sub-indices that characterize the depth of financial institutions has intensified in Azerbaijan. The activities of insurance companies in the country improved, and the share of the assets of these companies in GDP increased from $0.54 \%$ to $1.17 \%$ for the period 2007-2014. It should be noted that this indicator was not high in Iran at that time (0.94\%), while in Turkey it increased from $2.51 \%$ to $3.87 \%$. 


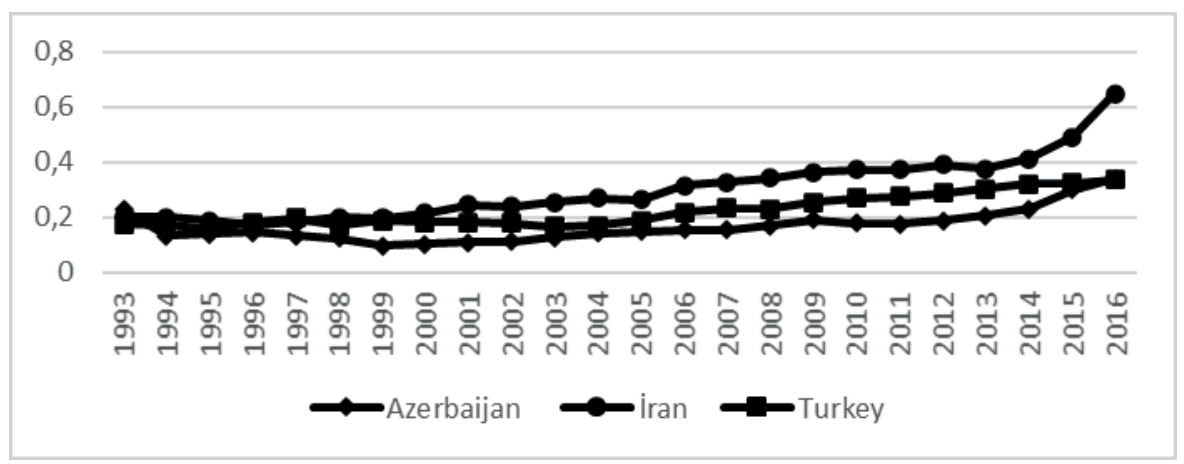

Figure 2. Financial Institutions Depth Index dynamics Source: authors' own elaboration based on GFDR (2018).

\section{A comparison of the banking systems of Azerbaijan, Turkey, and Iran on the Financial Institutions Effectiveness Index (FIEI)}

The dynamics of the ten main sub-indices that characterize the effectiveness of financial institutions in Azerbaijan for the period 1993-2016 show that the ratio of bank expenses to incomes in Azerbaijan developed in waves. However, despite short-term growth and decline, there is a tendency for this relationship to grow in the long run. This result can be associated with both a reduction in income and an increase in expenses. However, in the long run, this is mostly associated with high costs. In the short term, the indicator of the difference between bank interest rates on loans and deposit rates increased and decreased in the studied years. However, in the long term, this indicator has a growth dynamic. The net interest margin of banks in these years underwent short-term fluctuations of 3-5\% during the period 1996-2001, but rapidly increased until 2005, reaching 10\%. However, in subsequent years, it fell sharply and in 2011 amounted to 4.75\%. Between 2012 and 2016, there were again fluctuations in the range of $4-7 \%$. The level of non-interest income is high in Azerbaijan's banks. In 2003, the ratio of non-interest income to total income exceeded $70 \%$, although this figure has been steadily declining, and in recent years has fluctuated around $20 \%$. For comparison, in Turkey, the ratio of non-interest income of banks to total income decreased from $36 \%$ (1996) to 25\% (2014). In Iran, this figure fluctuated between 20-30\% over the years.

If short-term fluctuations and differences in this indicator are not taken into account, then the indicators of all three countries are gradually approaching each other (Figure 3). 


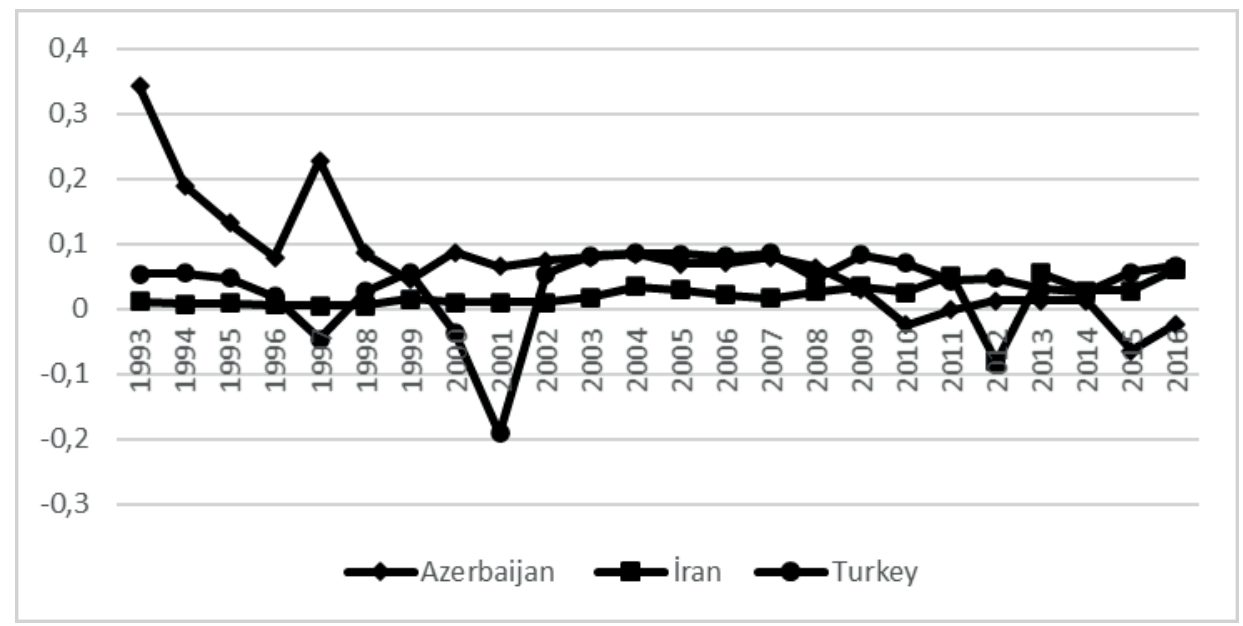

Figure 3. Financial Institutions Stability Index dynamics Source: authors' own elaboration based on GFDR (2018).

\section{A comparison of the banking systems of Azerbaijan, Turkey, and Iran on the Financial Institutions Stability Index (FISI)}

A comparative analysis of the FISI for the three countries shows (Figure 4) that the stability of financial institutions in Iran, where Islamic banking is used, is higher. Turkey's performance exceeds Azerbaijan's after 2009, although this indicator is lower in both countries compared to Iran.

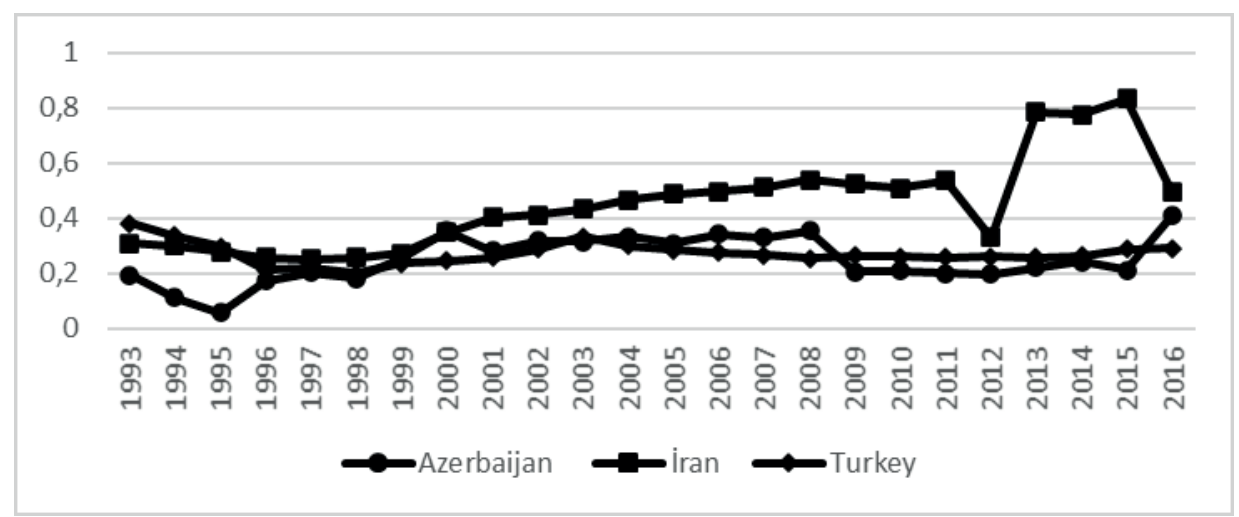

Figure 4. Financial Institutions Stability Index (FISI) dynamics Source: authors' own elaboration based on GFDR (2018). 


\section{The effectiveness of financial institutions}

The relationship between the composite Financial Institutions Effectiveness Index (FIEI) and GDP growth rate, as well as the volume of GDP p.c., is polynomial in calculating these relationships. When calculating the FIEI, two of the ten subindexes, i.e., the ratio of bank expenses to income and the ratio of bank expenses to total assets, are included in the composite index with a negative sign and subtracted from the general indicators. The indexed value of the remaining indicators is included in the composite index with a positive sign.

Our calculations show that there is no linear regression between the Financial Institutions Effectiveness Index (FIEI) and GDP growth rates. When calculating the relationship between GDP volumes, two of the ten sub-indices, i.e., the ratio of bank expenses to income and the ratio of bank operating expenses to total assets, are not included in aggregated indices, including a negative index. The relationship between the FIEI composite index and the economic growth rate, as well as the volume of GDP p. c. calculated on the basis of these indicators, is weak.

A regression analysis of the dependence of the rate of economic growth on sub-indices of the Efficiency of Financial Institutions over the past 16 years shows that in Azerbaijan, the rate of economic growth mainly depends on three sub-indices -1 ) the bank's net interest margin; 2) the ratio of non-interest income of the bank to total income; 3) the ratio of loans granted to state-owned enterprises to the volume of GDP. Dependence on the other seven sub-indices is negligible.

The calculations demonstrate there is a negative connection between Azerbaijan's rate of economic growth and the net interest margin of the bank, the ratio of non-interest income of the bank to total income, and the ratio of loans granted to state-owned enterprises to the volume of GDP (Table 1).

Table 1. Dependence of the GDP growth rate on the sub-indices of the Financial Institutions Effectiveness Index in Azerbaijan

\begin{tabular}{|l|c|c|c|c|}
\cline { 2 - 5 } \multicolumn{1}{c|}{} & Coefficient & Standard error & t-statistics & P-value \\
\hline Y intersection & 5716.38 & 1456.6 & 3.92 & 0.011 \\
\hline $\begin{array}{l}\text { Net interest margin of the } \\
\text { bank (\%) }\end{array}$ & -400.95 & 109.7 & -3.66 & 0.015 \\
\hline $\begin{array}{l}\text { The ratio of non-interest } \\
\text { income of the bank to total } \\
\text { income (\%) }\end{array}$ & -37.18 & 12.0 & -3.11 & 0.027 \\
\hline $\begin{array}{l}\text { The ratio of loans granted } \\
\text { to state enterprises to the } \\
\text { volume of GDP (\%) }\end{array}$ & -123.59 & 34.6 & -3.57 & 0.016 \\
\hline F significance = 0.001 & Multiple R=0.99 & Standard error =165.16 & observations =16 \\
\hline
\end{tabular}

Source: authors' calculation based on GFDR (2018) and World Bank (2018).

Iran's economic growth rate strongly depends on only one of the indicators described above, which characterizes the efficiency of the financial system - the ratio 
of loans granted to state-owned enterprises to the volume of GDP and this dependence is positive, unlike in Azerbaijan (Table 2).

Table 2. Dependence of the GDP growth rate on the sub-indices of the Financial Institutions Effectiveness Index in Iran

\begin{tabular}{|l|c|c|c|c|}
\cline { 2 - 5 } \multicolumn{1}{c|}{} & Coefficient & Standard error & t-statistic & P-value \\
\hline Y intersection & 199.57 & 52.71 & 3.79 & 0.001 \\
\hline $\begin{array}{l}\text { The ratio of loans grant- } \\
\text { ed to state enterprises } \\
\text { to the volume of GDP (\%) }\end{array}$ & 66.54251 & 11.57018 & 5.75 & 0.000 \\
\hline F significance =0.000 & Multiple R=0.77 & Standard error =176.5 & \multicolumn{2}{c|}{ observations =24 } \\
\hline
\end{tabular}

Source: authors' calculation based on GFDR (2018) and World Bank (2018).

The dependence of the GDP growth rate in Turkey on the sub-indices as the ratio of bank expenses to income, net interest margin of the bank, the ratio of non-interest income of the bank to total income, the profitability of bank capital show that Turkey's economic growth rate strongly and negatively depends on only four of the ten sub-indices that characterize the effectiveness of financial institutions (Table 3 ). The dependence on the remaining six indicators is weak.

Table 3. The dependence of the GDP growth rate on the sub-indices of the Financial Institutions Effectiveness Index in Turkey

\begin{tabular}{|l|c|c|c|c|}
\cline { 2 - 5 } \multicolumn{1}{c|}{} & Coefficient & Standard error & t-statistic & P-value \\
\hline Y intersection & 1268.92 & 128.68 & 9.86 & 0.000 \\
\hline $\begin{array}{l}\text { The ratio of bank } \\
\text { expenses to income (\%) }\end{array}$ & -8.70 & 1.91 & -4.57 & 0.000 \\
\hline $\begin{array}{l}\text { Net interest margin } \\
\text { of the bank (\%) }\end{array}$ & -25.34 & 8.90 & -2.85 & 0.014 \\
\hline $\begin{array}{l}\text { The ratio of non-interest } \\
\text { income of the bank } \\
\text { to total income (\%) }\end{array}$ & -8.21 & 2.34 & -3.51 & 0.004 \\
\hline $\begin{array}{l}\text { return on bank capital } \\
\text { (\%, before tax) }\end{array}$ & -9.63 & 3.69 & -2.61 & 0.022 \\
\hline F significance =0.000 & Multiple R=0.96 & Standard error =51.11 & observations =21 \\
\hline
\end{tabular}

Source: authors' calculation based on GFDR (2018) and World Bank (2018).

When calculating the FISI using seven stability sub-indices of financial institutions, we will enter only one indicator (the ratio of bank loans to bank deposits) in the composite index with a negative sign. High values of this indicator adversely affect stability. If one introduces other indicators in the FISI with a positive sign and calculate and comparatively analyse the impact of this indicator on the GDP growth rate, including the volume of GDP p.c. for Azerbaijan, Turkey, and Iran, it will become obvious that the correlation between these three indicators is weak for all three countries.

Analysing the dependence of the economic growth rate on the stability indicator of financial institutions using the example of financial institutions of Azerbaijan 
based on data for a 21-year period, we can determine that only two of the indicators, i.e., "the ratio of bank loans to bank deposits" and "the ratio of liquid assets to deposits and short-term financing," have a strong correlation with the rate of economic growth (Table 4).

Table 4. Dependence of GDP growth rate $(1993=100)$ on sub-indices of Financial Institutions in Azerbaijan

\begin{tabular}{|l|c|c|c|c|}
\cline { 2 - 5 } \multicolumn{1}{c|}{} & Coefficient & Standard error & t-statistic & P-value \\
\hline Y intersection & -14.93 & 269.68 & -0.06 & 0.956 \\
\hline $\begin{array}{l}\text { The ratio of bank loans to bank } \\
\text { deposits (\%) }\end{array}$ & 11.16 & 1.26 & 8.84 & 0.000 \\
\hline $\begin{array}{l}\text { Ratio of liquid assets to deposits } \\
\text { and short-term financing (\%) }\end{array}$ & -10.59 & 4.51 & -2.34 & 0.031 \\
\hline F significance =8.78E-10 & Multiple R =0.95 & Standard error =223.19 & Observations =21 \\
\hline
\end{tabular}

Source: authors' calculation based on GFDR (2018) and World Bank (2018).

Analyzing the dependence of the economic growth rate on the FISI using the example of Iranian financial institutions based on data from a 24-year period, it can be determined that only one of the indicators, "the ratio of bank loans to bank deposits," has a strong correlation with the rate of economic growth (Table 5).

Table 5. Dependence of the GDP growth rate $(1993=100)$ on the stability sub-indices of Financial Institutions in Iran

\begin{tabular}{|l|c|c|c|c|}
\cline { 2 - 5 } \multicolumn{1}{c|}{} & Coefficient & Standard error & t-statistic & P-value \\
\hline Y intersection & -417.13 & 156.13 & -2.67171 & 0.014 \\
\hline $\begin{array}{l}\text { The ratio of bank loans to bank } \\
\text { deposits (\%) }\end{array}$ & -417.13 & 1.86 & 5.523661 & 0.000 \\
\hline F significance $=0.000$ & Multiple R =0.76 & Standard error =180.79 & Observations =24 \\
\hline
\end{tabular}

Source: authors' calculation based on GFDR (2018) and World Bank (2018).

Analysing the dependence of the economic growth rate on the stability indicator of financial institutions using the example of financial institutions in Turkey based on data for an 18-year period, we can determine that five of the possible seven indicators, i.e., "the ratio of bank capital to total assets," "the ratio of bank loans to bank deposits," "the ratio of non-performing loans to total loans," "Z-account of the bank," and "The ratio of liquid assets to deposits and short-term financing" have a strong correlation with the rate of economic growth (Table 6).

The results of the regression analysis given in Tables 4-6 show that the influence of the financial system's stability on economic growth in Azerbaijan, Iran, and Turkey is different. The economic growth rates and the ratio of bank loans to bank deposits in Azerbaijan and Turkey are connected positively, but negatively in Iran. 
M. G. Gulaliyev, E. N. Rahimov, F. Sh. Kashiyeva, A. T. Huseynova, S. M. Alijanova, Y. A. Hakimova

Table 6. The dependence of the GDP growth rate $(1993=100)$ on the stability sub-indices of Financial Institutions in Turkey

\begin{tabular}{|l|c|c|c|c|}
\cline { 2 - 5 } \multicolumn{1}{c|}{} & Coefficient & Standard error & t-statistic & P-value \\
\hline Y intersection & 421.5389 & 110.8336 & 3.803349 & 0.003 \\
\hline $\begin{array}{l}\text { The ratio of bank capital } \\
\text { to total assets (\%) }\end{array}$ & 16.63862 & 7.230392 & 2.301206 & 0.044 \\
\hline $\begin{array}{l}\text { The ratio of bank loans } \\
\text { to bank deposits (\%) }\end{array}$ & 1.694942 & 0.360881 & 4.696675 & 0.001 \\
\hline $\begin{array}{l}\text { The ratio of non-performing } \\
\text { loans to gross loans (\%) }\end{array}$ & -8.48512 & 2.698632 & -3.14423 & 0.010 \\
\hline Bank Z-account & -20.0498 & 6.153906 & -3.25806 & 0.009 \\
\hline $\begin{array}{l}\text { Ratio of liquid assets } \\
\text { to deposits and short-term } \\
\text { financing (\%) }\end{array}$ & -3.42435 & 0.864444 & -3.96133 & 0.003 \\
\hline F significance =0.000 & Multiple R R =0.99 & Standard error =22.85 & Observations =21 \\
\hline
\end{tabular}

Source: authors' calculation based on GFDR (2018) and World Bank (2018).

\section{Discussion}

The indicators of the economic growth rate were calculated in comparison with 1993. Connections can be expressed as a polynomial function. In this case, the maximum economic growth corresponds to a certain limit of the FIDI. In other words, the connection between economic growth and the FIDI can be positive, to a certain limit, and after that, it can be negative. These results in Azerbaijan, Iran, and Turkey cases on a comparative analysis of traditional and Islamic banking are close to the results of studies conducted by Liang and Teng (2006), Estrada et al. (2010), Samargandi et al. (2015), and Borlea et al. (2016).

\section{Conclusion}

Evaluating countries' ratings according to the above-mentioned indices shows that the FISI of countries with a GDP p.c. of more than $\$ 20,000$ is in the range [0.1-0.3]. Countries with GDP p.c. in the right or left of this interval have much less than $\$ 20,000$. In Iran, where the absolute Islamic banking model is used, this indicator has 0.065 points and is far beyond this interval.

The fact that the FISI of high-income countries is in the range [0.1-0.3] allows us to say that the stability of the banking system in this interval is necessary for economic development. However, we note that this is not a sufficient condition. Most of the countries in this interval are countries with a GDP p.c. less than $\$ 10,000$. The FISI rating of countries with a GDP p.c. over $\$ 20,000$ shows that even in this group, there is a "narrower" interval for high-income countries. The relationship between the FISI 
and GDP p.c. means that for every country, there is an optimal stability interval. But when the country's FISI is in the range [0.1-0.3], the necessary conditions are created for its economic development.

The results show that the stability of financial institutions in Iran, where Islamic banking is used, is higher, according to FISI. Turkey's performance exceeds that of Azerbaijan after 2009. However, this indicator is lower in both countries compared to Iran. The study also shows that there is a strong dependence of the GDP growth rate on the sub-indices of the effectiveness of Financial Institutions in Azerbaijan, Turkey, and Iran.

The results of the regression analysis show that the influence of the stability of the financial system on economic growth in Azerbaijan, Iran, and Turkey is different. The economic growth rates and the ratio of bank loans to bank deposits in Azerbaijan and Turkey are positively related, but negatively in Iran.

\section{References}

Al-Malkawi, H.A.N., Marashdeh, H.A., Abdullah, N. (2012), Financial development and economic growth in the UAE: Empirical assessment using ARDL approach to co-integration, "International Journal of Economics and Finance", 4 (5), pp. 105115, https://doi.org/10.5539/ijef.v4n5p105

Ang, J., McKibbin, W. (2007), Financial liberalization, financial sector development and growth: Evidence from Malaysia, "Journal of Development Economics", 84 (1), pp. 215-233, https://doi.org/10.1016/j.jdeveco.2006.11.006

Bayar Y. (2014), Financial Development and Economic Growth in Emerging Asian Countries, "Asian Social Science", Vol. 10, No. 9, https://doi.org/10.5539/ass.v10n9p8

Borlea, S.N., Mare, C., Achim, M.V., \& Puscas, A. (2016), Direction of Causality Between Financial Development and Economic Growth. Evidence for Developing Countries, "Studia Universitatis “Vasile Goldis” Arad - Economics Series”, 26 (2), pp. 1-22, https://doi.org/10.1515/sues-2016-0006

Cámara, N. (2017), Measuring financial inclusion: a multidimensional index, Bank of Morocco - CEMLA - IFC Satellite Seminar at the ISI World Statistics Congress on "Financial Inclusion" Marrakech, Morocco, 14 July 2017, https://www.bis.org/ifc /publ/ifcb47p.pdf (accessed: 27.10.2019).

De Gregorio, J., Guidotti, P. (1995), Financial development and economic growth, "World Development", 23 (3), pp. 433-448, https://doi.org/10.1016/0305-750X(94 )00132-I

Estrada, G.B., Park, D., Ramayandi, A. (2010), Financial Development and Economic Growth in Developing Asia, Asian Development Bank Economics Working Paper No. 233, http://dx.doi.org/10.2139/ssrn.1751833

GFDR, (2018), World Bank. Global Financial Development Report, https://datacatalog .worldbank.org/dataset/global-financial-development (accessed: 30.10.2019).

Gulaliyev, M.G., Ashurbayli-Huseynova, N.P., Gubadova, A.A., Ahmedov, B.N., Mammadova, G.M., Jafarova, R.T. (2019), Stability of the banking sector: deriving stabil- 
ity indicators and stress-testing, "Polish Journal of Management Studies", 19 (2), pp. 182-195.

Hassan, K., Yu, J., Sanchez, B. (2011), Financial development and economic growth: New evidence from panel data, "The Quarterly Review of Economics and Finance", 51, pp. 88-104, https://doi.org/10.1016/j.qref.2010.09.001

Hye, Q.M.A. (2011), Financial development index and economic growth: empirical evidence from India, "The Journal of Risk Finance”, 12 (2), pp. 98-111, https://doi.org $/ 10.1108 / 15265941111112820$

Khan, M. Senhadji, A. (2000), Financial Development and Economic Growth: An Overview, IMF Working Papers, 00 (209), https://www.imf.org/external/pubs/ft/wp/20 00/wp00209.pdf (accessed: 30.10.2019).

King, R., Levine, R. (1993), Finance and growth: Schumpeter might be right, "The Quarterly Journal of Economics”, 108 (3), pp. 717-737, https://doi.org/10.2307/2118406

Levine, R., Loayza, N., Beck, T. (2000), Financial intermediation and growth: Causality and causes, "Journal of Monetary Economics", 46 (1), pp. 31-77, https://doi.org /10.1016/S0304-3932(00)00017-9

Liang, Q., Teng, J. (2006), Financial development and economic growth: Evidence from China, "China Economic Review", 17 (4), pp. 395-411, https://doi.org/10.1016/j.ch ieco.2005.09.003

Samargandi, N., Fidrmuc, J., Ghosh, S. (2015), Is the relationship between financial development and economic growth monotonic? Evidence from a sample of middle-income countries, "World Development", 68, pp. 66-81, https://doi.org/10.1016/j.wor lddev.2014.11.010

Schumpeter, J. (1912), The Theory of Economic Development, Harvard University Press, Cambridge.

Svirydzenka, K. (2016), Introducing a New Broad-based Index of Financial Development, IMF Working Paper Strategy, Policy, and Review Department, https://www .imf.org/external/pubs/ft/wp/2016/wp1605.pdf (accessed: 30.10.2019).

World Bank (2018), GDP growth (annual \%), https://data.worldbank.org/indicator/NY .GDP.MKTP.KD.ZG (accessed: 30.11.2019). 


\section{Efektywność ekonomiczna bankowości tradycyjnej i islamskiej (analiza porównawcza sektora bankowego w Turcji, Azerbejdżanie i Iranie)}

W artykule podjęto próbę opracowania metodologii oceny porównawczej efektywności ekonomicznej banków, w tym modelu bankowości tradycyjnej i islamskiej. Wyniki oceny wskazują, że stabilność instytucji finansowych w Azerbejdżanie jest niższa w porównaniu z bankami, w których stosuje się bankowość islamską. Jak wynika z oceny, istnieje silna zależność stopy wzrostu PKB od wskaźników częściowych dotyczących skuteczności instytucji finansowych w Azerbejdżanie, Turcji i Iranie. Zastosowano metodologię regresji liniowej i złożony wskaźnik efektywności ekonomicznej banków. Wyniki oceny pokazują, że wpływ stabilności systemu finansowego na wzrost gospodarczy w Azerbejdżanie, Iranie i Turcji jest różny. Ponieważ tempo wzrostu gospodarczego i stosunek kredytów bankowych do depozytów bankowych są dodatnio powiązane w Azerbejdżanie i Turcji, ale negatywnie w Iranie.

Słowa kluczowe: instytucje finansowe, dostęp do instytucji finansowych, głębokość instytucji finansowych, efektywność instytucji finansowych, stabilność instytucji finansowych 